\title{
PENGARUH KONSUMSI DAUN KELOR (Moringa oleifera) TERHADAP VO2MAX DAN LACTATE THRESHOLD
}

\author{
Calvin Chandra ${ }^{1}$, Hamidie Ronald Daniel Ray ${ }^{1,2}$ \\ ${ }^{1}$ Fakultas Pendidikan Olahraga dan Kesehatan, Universitas Pendidikan Indonesia, Indonesia; \\ ${ }^{2}$ Fakultas Human Sciences, Universitas Kanazawa, Ishikawa, Jepang
}

\begin{abstract}
This research aims to determine how the effect of combination of Moringa Leaf consumption with aerobic exercise against VO2Max and Lactate Threshold as ergogenic aids. 16 Taekwondo athletes are participated in this research. Participants are divided into 2 groups: the experimental group, which has been given the treatment of Moringa leaves and aerobic exercise, and the control group, which has been given an aerobic treatment only. The method used is experimental method with randomized pretest-posttest comparison group design. This research took 6 weeks length with aerobic exercise 4 days a week. Moring leaves consumed at a dose of $2000 \mathrm{mg}$ during treatment. The data collection used a Balke Test to measure the VO2max and modified Conconi Test to measure the lactate threshold. The results of this research showed a significant increase in mean before and after treatment in both variables from each group $(p<0.05)$. However, the value of the increase in both variables between the two groups did not show significant difference $(p>0.05)$. These results, it can be concluded that there is a significant increase of VO2Max and Lactate Threshold between pre test and post test in each group, but there is no significant difference from deviation of increase of between control and experiment group although the experimental group increase is higher than the control group.
\end{abstract}

Keywords: VO2Max, Lactate Threshold, Moringa Leaf, Ergogenic Aids. 


\section{PENDAHULUAN}

Pada dunia olahraga khususnya olahraga yang bertujuan memperoleh penghargaan prestasi tertinggi, membutuhkan kondisi fisik yang prima agar menunjukan performa yang maksimal. Banyak aspek fisiologi yang dapat mempengaruhi performa olahraga, contohnya $\mathrm{VO}_{2}$ max dan Lactate Threshold (LT) ${ }^{1} \quad \mathrm{VO}_{2} \mathrm{Max}$ adalah didefinisikan sebagai kapasitas maksimum dari sistem paru, kardiovaskular dan otot untuk mengambil, mengangkut dan memanfaatkan $\mathrm{O} 2^{2}$ dan LT adalah intensitas latihan di mana konsentrasi laktat darah mulai meningkat secara signifikan dibandingkan dengan nilai saat istirahat dan berkaitan dengan ambang anaerobik ${ }^{3}$. VO2Max dan LT adalah factor utama dalam olahraga daya tahan ${ }^{4}$.Untuk meningkatkan kemampuan daya tahan tersebut selain latihan dapat juga dilakukan dengan kombinasi latihan dan ergogenic aids ${ }^{5}$

Ergogenic aids mengacu pada substansi apa pun yang dapat meningkatkan kapasitas kerja tubuh atau mental, terutama oleh menghilangkan gejala kelelahan ${ }^{6}$. Terdapat 2 jenis ergogenic aids seperti yang dijelaskan oleh yaitu Nutritional ergogenic aids dan nonnutritional ergogenic aids. Nutritional ergogenic aids mengacu pada substansi yang dapat meningkatkan peforma di dapat dari nutrisi baik, metabolisme dari produk nutrisi, ekstrak makanan (tumbuhan), atau zat yang biasa ditemukan pada makanan (misalnya kafein dan kreatin) yang disediakan dalam jumlah banyak. Selanjutnya nonnutritional ergogenic aids adalah substansi yang dapat meningkatkan peforma seperti dari zat tertentu seperti steroid anabolik dan lainnya, yang digunakan oleh atlet, namun ergogenic aids tersebut dilarang secara universal oleh badan organisasi olahraga (NCAA, IOC, USOC, dan sebagainya). ${ }^{6}$ Maka dari itu banyak pelaku olahraga seperti atlet, pelatih atau pakar nutrisi olahraga menggunakan ergogenic aids berbahan alami ${ }^{7}$. Banyak penelitian yang mengungkapkan bahwa tumbuhan alami dapat dijadikan ergogenic aids, salah satunya penelitian tentang kunyit yang dapat meningkatkan biogenesis motokondria pada skeletal muscle ${ }^{8}$. Selain itu terdapat juga penelitian pada zat yang terkandung pada tumbuhan alami yang berhubungan dengan $\mathrm{VO}_{2} \mathrm{Max}$ dan LT, seperti pemberian caffeine, carnitine, and choline pada dosis tertentu dapat meningkatkan $\mathrm{VO}_{2}$ max dan menurunkan konsentrasi laktat ${ }^{9}$. Selain kunyit terdapat beberapa tumbuhan alami yang berpotensi menjadi ergogenic aids dan bermanfaatbagi tubuh, contohnya tumbuhan daun kelor.
Daun kelor adalah tanaman yang dapat tumbuh di daerah kering, tropis dan subtropics, daun kelor kaya akan mineral dan vitamin kaya selain itu kandungan protein, zat besi, kalium, kalsium, dan potassium cukup tinggi ${ }^{10}$. Pemanfaatan daun kelor terhadap ergogenic aids telah dibuktikan oleh penelitian sebelumnya mengungkapkan bahwa daun kelor meningkatkan waktu berenang maksimum, hemoglobin darah, glukosa darah, dan cadangan glikogen hati dan otot. Selanjutnya daun kelor meningkatkan aktivitas enzim antioksidan dan menurunkan konsentrasi malondialdehid darah kemudian daun kelor menurunkan konsentrasi laktat, trigliserida, dan urea dalam darah, Terakhir sifat anti kelelahan pada daun kelor mampu memperbaiki cadangan energi tubuh dan kapasitas antioksidan jaringan dan untuk mengurangi pembentukan jaringan asam laktat ${ }^{11}$ Berdasarkan penelitian di atas daun kelor sangat berpotensi sebagai ergogenic aids, maka dari itu peneliti ingin mengetahui pengaruh konsumsi daun kelor terhadap $\mathrm{VO}_{2} \max$ dan LT.

\section{METODE PENELITIAN}

\section{Design Penelitian}

Pada penelitian ini menggunakan metode eksprimen dan menggunakan design penelitian The Randomized Pretest-Posttest Control Group Design

\section{Sampel}

sampel yang digunakan adalah atlet pelatcab taekwondo kota cimahi sebanyak 16 orang

\section{Instrument}

Instrumen pengambilan data menggunakan balke test untuk mengukur $\mathrm{VO}_{2}$ max ${ }^{12}$ dan modified conconi test untuk mengukur lactate threshold $^{13}$

\section{Prosedur Penelitian}

Pada awal penelitian, seluruh sampel melakukan pretest untuk menentukan kemampuan awal sampel, pengukuran $\mathrm{VO}_{2}$ max dengan Balke test dan lactate threshold dengan modified conconi test. selanjutnya sampel dibagi secara acak menjadi 2 kelompok, yaitu kelopok eksperiman dan kelompok control. Kelompok eksperimen diberikan perlakuan berupa pemberian daun kelor dan latihan aerobik lalu kelompok kontrol hanya diberikan latihan aerobic.trearment yang diberikanberdurasi selama 6 minggu $^{14 .}$ Daun kelor dikonsumsi yang berupa kapsul dengan dosis 2000 mg/hari (@) kapsul 500 
mg )selama periode treatment. Latihan aerobik yang diberikan adalah jenis jogging dilakukan sebanyak 4 kali dalam seminggu dengan durasi 30 menit pada intensitas vigorous (60-90\% denyut nadi maksimal) yang mengacu kepada panduan American College of Sports Medicine ${ }^{14}$ dengan metode latihan continuous training ${ }^{1}$ Pada akhir penelitian dilakukan pretest untuk melihat pengaruh treatmen yang di berikan terhadap $\mathrm{VO}_{2}$ max dan lactate threshold.

\section{HASIL PENELITIAN}

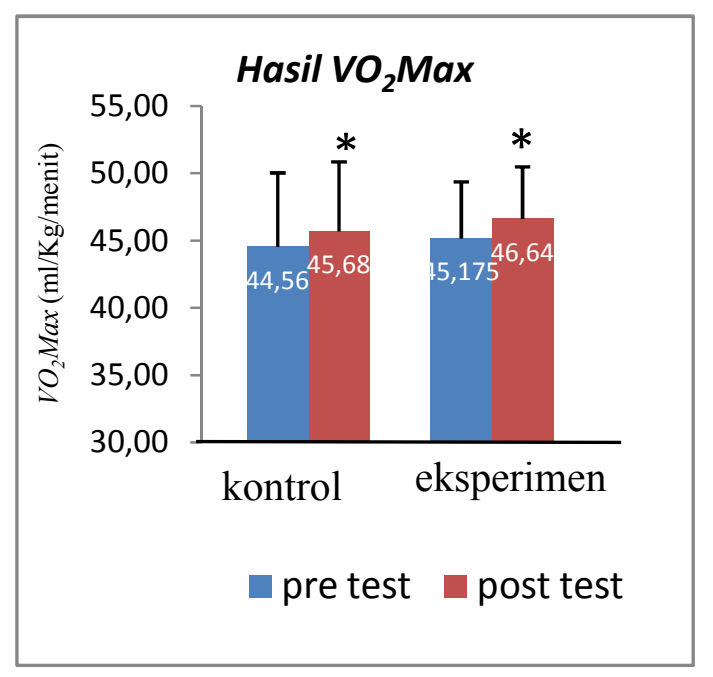

Gambar 1. Perbandingan nilai rata-rata $\mathrm{VO}_{2} \mathrm{Max}$ $(\mathrm{ml} / \mathrm{kg} / \mathrm{min})$ antara sebelum dan sesudah treatment pada kelompok control dan kelompok eksperimen

Gambar 1 menunjukan grafik nilai rata-rata $\mathrm{VO}_{2} \mathrm{Max}$ dari setiap kelompok pada pre test dan post test. Pada grafik tersebut menunjukan nilai rata-rata $\mathrm{VO}_{2}$ Max kelompok eksperimen pada saat pre test sebesar $45.175 \mathrm{ml} / \mathrm{kg} / \mathrm{min}$ dan pada saat post test meningkat menjadi $46.64 \mathrm{ml} / \mathrm{kg} / \mathrm{min}$ dengan nilai rata-rata kenaikan sebesar $\quad 1.46 \mathrm{ml} / \mathrm{kg} / \mathrm{min}$. Sedangkan pada kelompok kontrol nilai rata-rata pre test sebesar 44.56 dan saat post test meningkat menjadi 45.68 dengan nilai rata-rata kenaikan sebesar $1.12 \mathrm{ml} / \mathrm{kg} / \mathrm{min}$.

Tabel 1 menunjukan nilai rata-rata kenaikan $\mathrm{VO}_{2} \mathrm{Max}$ pada kelompok eksperimen sebesar 1.46 $\mathrm{ml} / \mathrm{kg} / \mathrm{min}$ dengan nilai taraf signifikansi sebesar 0.000 , sedangkan pada kelompok kontrol nilai ratarata kenaikan $\mathrm{VO}_{2} \mathrm{Max}$ sebesar $1.12 \mathrm{ml} / \mathrm{kg} / \mathrm{min}$ dengan nilai nilai taraf signifikansi sebesar 0.003. Kedua kelompok menunjukan nilai taraf signifikan lebih kecil dari pada nilai alpa $(\mathrm{p}<0.05)$. Dari hasil tersebut maka dapat interpretasikan terdapat perbedaan yang signifikan, antara sebelum dan sesudah treatmen.
Tabel 1. Hasil Statistika $\mathrm{VO}_{2} \mathrm{Max}(\mathrm{ml} / \mathrm{kg} / \mathrm{min})$

\begin{tabular}{lcccc}
\hline Kelompok & N & Mean & $\begin{array}{c}\text { Std. } \\
\text { Dev }\end{array}$ & Sig. \\
\hline $\begin{array}{l}\text { eksperimen } \\
\text { (Daun Kelor }+\end{array}$ & 8 & 1.46 & 0.492 & 0.000 \\
$\begin{array}{l}\text { latihan } \\
\text { aerobik) }\end{array}$ & & & & \\
$\begin{array}{l}\text { Kontrol } \\
\text { (latihan } \\
\text { aerobic) }\end{array}$ & 8 & 1.12 & 0.706 & 0.003 \\
\hline
\end{tabular}

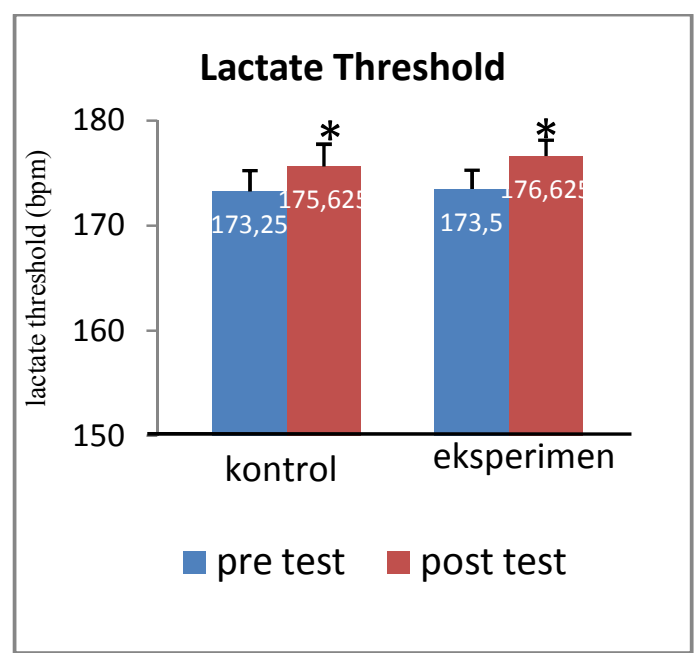

Gambar 2. Perbandingan nilai rata-rata Lactate Threshold (BPM) antara sebelum dan sesudah treatment pada kelompok control dan kelompok eksperimen

Gambar 2 menunjukan grafik data nilai Lactate Threshold dari setiap kelompok pada saat pre test dan post test. Pada grafik tersebut menunjukan nilai rata-rata Lactate Threshold kelompok eksperimen pada saat pre test sebesar $173.5 \mathrm{bpm}$ dan pada saat post test meningkat menjadi $176.63 \mathrm{bpm}$ dengan nilai rata-rata kenaikan sebesar $3.125 \mathrm{bpm}$. Sedangkan pada kelompok kontrol nilai rata-rata pre test sebesar173.23 dan saat post test meningkat menjadi $175.63 \mathrm{bpm}$ dengan nilai rata-rata kenaikan sebesar $2.375 \mathrm{bpm}$.

Tabel 1 menunjukan nilai rata-rata kenaikan $\mathrm{VO}_{2} \mathrm{Max}$ pada kelompok eksperimen sebesar 1.46 $\mathrm{ml} / \mathrm{kg} / \mathrm{min}$ dengan nilai taraf signifikansi sebesar 0.000 , sedangkan pada kelompok kontrol nilai ratarata kenaikan $\mathrm{VO}_{2} \mathrm{Max}$ sebesar $1.12 \mathrm{ml} / \mathrm{kg} / \mathrm{min}$ dengan nilai nilai taraf signifikansi sebesar 0.003 . Kedua kelompok menunjukan nilai taraf signifikan lebih kecil dari pada nilai alpa $(\mathrm{p}<0.05)$. Dari hasil tersebut maka dapat interpretasikan terdapat perbedaan yang signifikan, antara sebelum dan sesudah treatmen. 
Tabel 2. Hasil Statistika Lactate Treshold (BPM)

\begin{tabular}{lcccc}
\hline Kelompok & N & Mean & $\begin{array}{c}\text { Std. } \\
\text { Dev }\end{array}$ & Sig. \\
\hline $\begin{array}{l}\text { eksperimen } \\
\text { (Daun Kelor }\end{array}$ & 8 & 3.125 & 1.3562 & 0.000 \\
$+\quad$ latihan & & & & \\
$\begin{array}{l}\text { aerobik) } \\
\begin{array}{l}\text { Kontrol } \\
\text { (latihan }\end{array}\end{array}$ & 8 & 2.375 & 1.767 & 0.007 \\
aerobic) & & & & \\
\hline
\end{tabular}

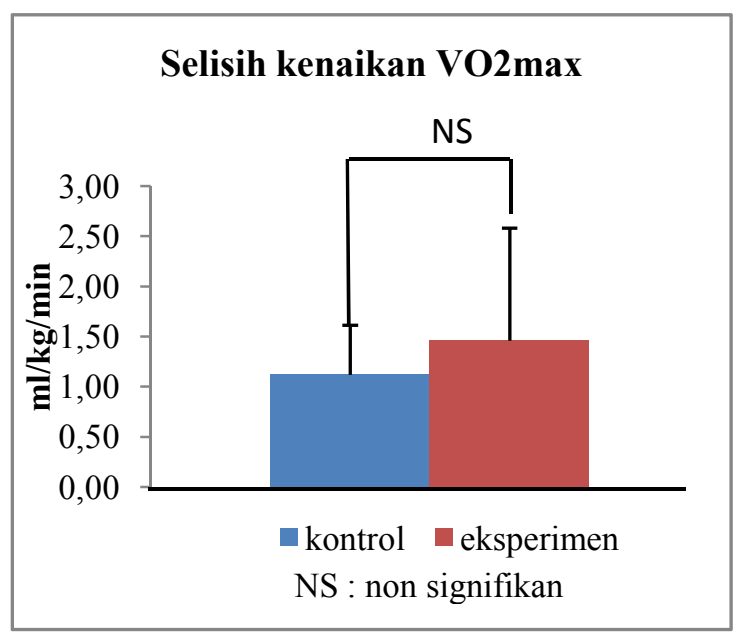

Gambar 3 Grafik Selisih Kenaikan Rata-Rata $\mathrm{VO}_{2} \mathrm{Max}$

Pada gambar 3 menampilkan grafik rata-rata selisih kenaikan $\mathrm{VO}_{2}$ Max pre test dan post test pada kelompok eksperimen dan kontrol. Grafik menunjukan nilai rata-rata selisih kenaikan $\mathrm{VO}_{2} \mathrm{Max}$ pada kelompok eksperimen sebesar 1.46 sedangkan pada kelompok kontrol sebesar 1.12.

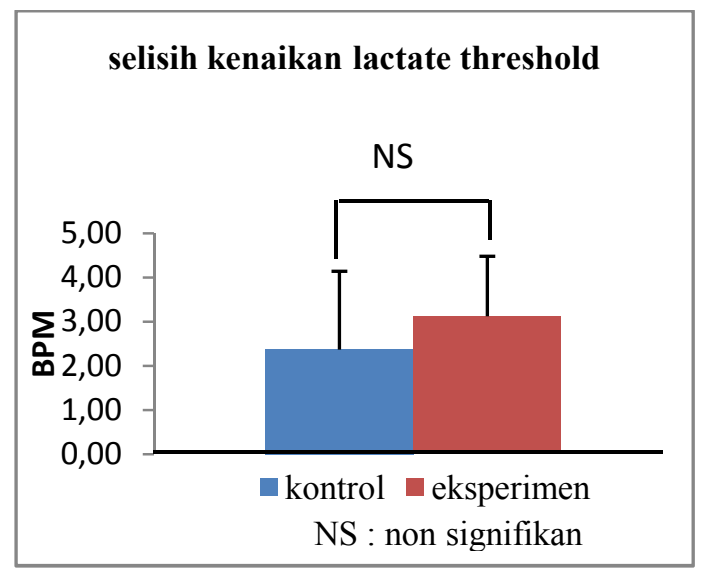

Gambar 4 Grafik Selisih Kenaikan Rata-Rata Lactate Threshold

Pada gambar 4. menampilkan rata-rata selisih kenaikan Lactate Threshold pre test dan post test pada kelompok eksperimen dan kontrol. Grafik menunjukan nilai rata-rata selisih kenaikan Lactate Threshold pada kelompok eksperimen sebesar 3.13 sedangkan pada kelompok kontrol sebesar 2.38

Tabel 3..nilai selisih kenaikan rata-rata $\mathrm{VO}_{2} \mathrm{Max}$ dan Lactate Treshold antara kelompok control dan eksperimen

\begin{tabular}{lcc}
\hline \multicolumn{1}{c}{ Variabel } & N & Sig. \\
\hline Selisih Kenaikan & 8 & 0.283 \\
$V \mathrm{O}_{2}$ MaxKelompok Eksperimen dan & & \\
$\begin{array}{l}\text { kontrol } \\
\text { Selisih KenaikanLactate Threshold }\end{array}$ & 8 & 0.118 \\
Kelompok Eksperimen dan kontrol & & \\
\hline
\end{tabular}

Tabel 3.menunjukan nilai taraf signifikasi perbedaan selisih kenaikan $\mathrm{VO}_{2} \mathrm{Max}$ antara kelompok kontrol dan eksperimen sebesar 0.283, Sedangkan nilai taraf signifikasi perbedaan selisih kenaikan Lactate Threshold antara kelompok kontrol dan eksperimen sebesar 0.118. Kedua variable tersebut menunjukan nilai taraf signifikan lebih besar dari pada nilai alpa $(\mathrm{p}>0.05)$. Dari hasil tersebut maka dapat interpretasikan tidak terdapat perbedaan yang signifikan, selisih kenaikan antara kelompok kontrol dan kelompok eksperimen.

\section{DISKUSI}

Penggunaan ergogenic aidstelah banyak dipakai untuk membantu meningkatkan performa saat berolahraga. Banyak ergogenic aids yang di teliti untuk meningkatkan performa olahraga. Meskipun banyak jenis ergogenic aids yang di temukan, tidak semuanya dari ergogenic aids tersebut boleh di gunakan secara legal. Maka dari itu banyak penelitian beralih pada bahan alami sebagai ergogenic aids yang berpotensi meningkatkan peforma olahraga. Di Indonesia banyak bermacam tumbuhan alami yang mudah di temukan dapat di teliti sebagai ergogenic aids salah satunya, daun kelor.

Daun kelor adalah tubuhan tropis dan subtropis yang mudah di temukan di Indonesia. Daun kelor biasanya di gunakan pada bidang kesehatan untuk mengobati berbagai kesehatan. Dalam salah satu sistem pengobatan dan perawatan kesehatan kuno (Ayurveda), kelor mampu mencegah atau mencegah 300 macam penyakit. ${ }^{15}$ Selain di gunakan dalam bidang kesehatan, penelitian sebelumnya membuktikan bahwa daun kelor dapat bermafaat dalam bidang olahraga. Salah satunya penelitian yang dilakukan oleh Bhattacharya, menyatakan bahwa pemberian ekstrak ethanol daun kelormemberikan aktivitas depresan system saraf pusat (SSP) dan aktivitas relaksasi otot ${ }^{16}$ 
Penelitian ini ingin melihat bagaimana pengaruh dari mengkonsumsi daun kelor terhadap peningkatan peforma olahraga. Banyak faktor yang mendukung peforma dalam olahraga termasuk $\mathrm{VO}_{2}$ Max dan lactate Threshold. Kedua hal ini sangat berkaitan dengan kemampuan daya tahan pada olahraga. Untuk memperoleh data $\mathrm{VO}_{2} \mathrm{Max}$ menggunakan instrumen balke test. Balke test merupakan tes yang umum untuk mengukur kemampuan $\mathrm{VO}_{2} \mathrm{Max}$ seseorang. Pada pengukuran Lactate Threshold menggunakan instrumen modified conconi test.Pengukuran Lactate Threshold yang lebih akurat dengan yaitu pengambilan sampel darah dari sampel untuk melihat kadar laktat dalam darahdengan pengambilan darah diambil pada ujung jari (fingertip) ${ }^{17}$. Alat yang di gunakan untuk melihat kadar laktat dalam darah adalah lactate analizer. Namun modified conconi test cukup akurat untuk memprediksi lactate threshold. ${ }^{13}$

Hasil temuan pada penelitian ini menunjukan kenaikan nilai rata-rata $\mathrm{VO}_{2} \mathrm{Max}$ pada kelompok eksperimen, dengan nilai awal sebesar 45.175 $\mathrm{ml} / \mathrm{kg} / \mathrm{min}$ setelah treadment menjadi 46.64 $\mathrm{ml} / \mathrm{kg} / \mathrm{min}$ dengan kenaikan sebesar $1.46 \mathrm{ml} / \mathrm{kg} / \mathrm{min}$ sedangkan pada kelompok kontrol nilai awal sebesar $44.56 \mathrm{ml} / \mathrm{kg} / \mathrm{min}$ setelah treadment menjadi 45.68 $\mathrm{ml} / \mathrm{kg} / \mathrm{min}$ dengan kenaikan sebesar $1.12 \mathrm{ml} / \mathrm{kg} / \mathrm{min}$. Pada pengujian statistik menunjukan bahwa kedua kelompok tersebutmeningkat secara signifikan $(\mathrm{p}<0.05)$ antara hasil pre test dan post test. hasil rata-rata kelompok eksperimen lebih besar dari pada kelompok kontrol.

Hasil penelitian ini juga menunjukan pergeseran nilai detak jantung lactate treshold pada setiap kelompok. Pada kelompok eksperimen dari nilai rata-rata awal sebesar $173.50 \mathrm{dpm}$ setelah dilakukan treatment menjadi $176.63 \mathrm{dpm}$ dengan kenaikan rata-rata sebesar $3.125 \mathrm{dpm}$ sedangkan pada kelompok kontrol nilai rata-rata awal sebesar $173.25 \mathrm{dpm}$ setelah treadment menjadi $175.63 \mathrm{dpm}$ dengan kenaikan sebesar $2.375 \mathrm{dpm}$. Pada pengujian statistik menunjukan bahwa kedua kelompok tersebut meningkat secara signifikan $(\mathrm{p}<0.05)$ antara hasil pre test dan post test. hasil rata-rata kelompok eksperimen lebih besar dari pada kelompok kontrol.

Pada nilai rata-rata selisih kenaikan $\mathrm{VO}_{2} \mathrm{Max}$ pada kelompok eksperimen menunjukan nilai sebesar sebesar 1.46 sedangkan pada kelompok kontrol sebesar 1.12. Kemudian pada nilai rata-rata selisih kenaikan lactate threshold pada kelompok eksperimen yang menunjukan nilai sebesar 3.13 sedangkan pada kelompok kontrol sebesar 2.38. pada data variabel tersebut dilakukan pengujian statistika yang menunjukan bahwa keduanya tidak terdapat perbedaan yang signifikan $(\mathrm{p}>0.05)$ nilai rata-rata selisih kenaikan $\mathrm{VO}_{2} \mathrm{Max}$ dan lactate threshold antara kelompok eksperimen dan kelompok kontrol.

Pada kedua hasil $\mathrm{VO}_{2} \mathrm{Max}$ dan lactate threshold tersebut didapatkan dari perlakuan yang di berikan, pada kelompok eksperimen yaitu berupa pemberian konsumsi ekstrak daun kelor sebanyak $2000 \mathrm{mg}$ dan latihan aerobik dengan jenis jogging dilakukan sebanyak 4 kali dalam seminggu dengan durasi 30 menit pada intensitas vigorous (60-90\% denyut nadi maksimal) yang mengacu kepada panduan American College of Sports Medicine. ${ }^{14}$ dengan metode latihan continuous training. ${ }^{1}$ selama 6 minggu. ${ }^{14}$ sedangkan kelompok kontrol hanya latihan aerobik seperti yang dijelaskan sebelumnya. Pada $\mathrm{VO}_{2} \mathrm{Max}$ sejalan dengan penelitian Gormley, yang menyatakan bahwa durasi latihan aerobik selama minimal 6 minggu dapat meningkatkan $\mathrm{VO}_{2} \mathrm{Max} .{ }^{18}$ Sedangkan pada lactate threshold hasil ini sejalan dengan dengan penelitian yang dilakukanGhosh ( 2004) latihan dengan intensitas tinggi tidak hanya dapat meningkatkan $\mathrm{VO}_{2} \mathrm{Max}$ tetapi juga meningkatkan lactate threshold. ${ }^{19}$

Hasil penelitian ini sejalan dengan dengan penelitian sebelumnya yang mengatakan bahwa konsumsi ekstrak daun kelor dapat meningkatkankadar hemoglobin dalam darah ${ }^{11}$, sementara penelitian lainnya mengungkapkanjumlah hemoglobin di dalam darah sangat berhubungan dengan $\mathrm{VO}_{2} \mathrm{Max}^{12}$ Sedangkan pada hasil lactate threshold juga berhubungan dengan penelitian sebelumnya yang mengatakan bahwa pemberian ekstrak daun kelor, dapat menurunkan konsentrasi laktat ${ }^{11}$. Hal ini sangat berhubungan dengan lactate threshold, karena jika konsentrasi asam laktat menurun maka akanberpengaruh juga terhadap lactate threshold. Walaupun terdapat pengaruh yang signifikan pada kelompok eksperimen dan kelompok kontrol, namun hasil lain menunjukan selisih kenaikan $\mathrm{VO}_{2} \mathrm{Max}$ dan lactate threshold antara kelompok eksperimen dan kontrol tidak terdapat perbedaan yang signifikan. walaupun hasil kelompok eksperien yang mengonsumsi daun kelor lebih tinggi

Tidak terdapatnya perbedaan hasil antara kelompok eksperimen dan kelompok kontrol di sinyalir karena kurangnya dosis yang di konsumsi. pada penelitian ini semua sampel pada kelompok eksperimen mengonsumsi daun kelor yang di keringkan sebanyak 2000mg sementara pada penelitiansebelumnya daun kelor yang digunakan berupa ekstrak dengan dosis minimal $100 \mathrm{mg} / \mathrm{kg}$ dapat memberikan pengaruh yang signifikan ${ }^{11}$ dengan kata lain jika sampel memiliki berat badan $60 \mathrm{~kg}$, maka sampel tersebut mengonsumsi daun kelor sebanyak 6000mg. Sementara berat badan sampel yang di gunakan 
pada penelitian ini berbeda-beda. Selain kurangnya dosis yang di gunakan, kurangnya dosis latihan disinyalir juga dapat mempengaruhi hasil penelitihan.Kurangnya waktu treatment dan durasi latihan dapat mempengaruhi hasil.Dalam sebuah penelitian oleh Osei-Tutu ${ }^{21}$ menunujukan latihan aerobik sebanyak 5 kali perminggu selama 8 minggu dengan durasi 10-30 menit dapat $\mathrm{VO}_{2} \max$ yang signifikan. Penelitian Pour-abdi ${ }^{22}$ menunjukan latihan interval jangka pendek selama 8 minggu dapat meningkatkan VO2max. selanjutnya penelitian dari Brito Vieira ${ }^{23}$ mengungkapkan latihan aerobik di treadmill selama 5 minggu dapat meningkatkan Lactate Threshold. selain itu penelitian dari Carte mengungkapkan latihan daya tahan selama 6 minggu dapat meningkatkan $\mathrm{VO}_{2} \mathrm{Max}$ dan lactate threshold ${ }^{24}$. Selain dosis konsumsi daun kelor dan dosus latihan, Faktor external juga dapat berpengaruh terhadap performa olahraga seperti lingkungan, emosional, dan waktu tidurdikarenakan sampel yang digunakan adalah manusia. Selanjutnya pernyataan Chan, $\mathrm{dkk}^{26}$ yang menyebutkan bahwa cuaca dapatmempengaruhi terhadapat aktivitas fisik, dikarenakan treatment latihan aerobik yang dilakukan pada lapangan terbuka.

\section{KESIMPULAN}

Berdasarkan penelitian ini dan uji hipotesis, tentang pengaruh konsumsi daun kelor kelor (moriga oleifera) terhadap $\mathrm{VO}_{2} \mathrm{Max}$ dan Lactate Threshold, di peroleh kesimpulan bahwa terdapat peningkatan yang signifikan $\mathrm{VO}_{2} \mathrm{Max}$ dan Lactate Threshold antara pre test dan post test pada kelompok kontrol dan kelompok ekperimen, namun tidak terdapat perbedaan yang signifikan, selisih kenaikan antara kelompok kontrol dan eksperimen walaupun kenaikan kelompok eksperimen lebih tinggi dari pada kelompok kontrol.

\section{DAFTAR PUSTAKA}

1. Kenney WL, Wilmore J, Costill D. Physiology of sport and exercise 6th edition. USA: Human kinetics; 2015.

2. Smirmaul BPC, Bertucci DR, \& Teixeira IP. Is the $\mathrm{VO}_{2} \max$ that we measure really maximal?. Frontiers in Physiol. 2013;10-13.

3. Etxegarai U, Portillo E, Irazusta J, Arriandiaga A, Cabanes I. Estimation of lactate threshold with machine learning techniques in recreational runners. Appl Soft Comput J. 2018;63,181-196.

4. Joyner MJ, Coyle EF. Endurance exercise performance: the physiology of champions. The $J$ of Physiol. 2008;586(1), 35-44.

5. Papadopoulou S, Kroustalloudi E, Pagkalos I. The Effect of Ergogenic Supplements and Mediterranean Diet on Cycling Performance; Differences According to Duration and Intensity. Arab $J$ of Nutr and Exercise. 2017;2(1),23-39.

6. Benardot, Dan. Advanced Sports Nutrition (2nd edition). United States of America: Human Kinetics; 2012.

7. Williams MH. The use of nutritional ergogenic aids in sports: is it an ethical issue? Internat $J$ of Sport Nutr. 1994;4(2), 120-131.

8. Ray HRD, Yamada T, Ishizawa R, Saito $Y$, Masuda K. Curcumin treatment enhances the effect of exercise on mitochondrial biogenesis in skeletal muscle by increasing cAMP levels. Metabol: Clin and Experiment. 2015;64(10),1334-1347.

9. Sachan DS, Hongu N. Increases in $\mathrm{VO}_{2} \mathrm{max}$ and metabolic markers of fat oxidation by caffeine, carnitine, and choline supplementation in rats. J of Nutr Biochem. 2000;11(10), 521-526.

10. Oyeyinka AT, Oyeyinka SA. Moringa oleifera as a food fortificant: Recent trends and prospects. $J$ of the Saudi Soc of Agricult Sci. 2018;17(2), 127-136.

11. Lamou B, Taiwe GS, Hamadou A, Abene, Houlray $\mathrm{J}$, Atour MM, et al. Antioxidant and antifatigue properties of the aqueous extract of moringa oleifera in rats subjected to forced swimming endurance test. Oxidative Med and Cell Longevity. 2016;7-10.

12.MacKenzie B. 101 Performance Evaluation Tests. London : Electric Word plc; 2005.

13. Kjertakov M, Dalip M, Hristovski R, Epstein Y. Prediction of lactate threshold using the modified Conconi test in distance runners. Acta Physiol Hungari. 2016;103(2),262-270.

14. Heyward VH. Advanced fitness assessment and exercise prescription Seventh Edi tion. United States of America : Human Kinetics; 2014.

15. Mardiana L. Daun Ajaib Tumpas Penyakit. Jakarta: Penebar Swadaya; 2012. 
16. BhattacharyaA, NaikMR, AgrawalD, SahuPK, Kumar, S, Mishra SS. Cns depressant and muscle relaxant effect of ethanolic leaf extract of Moringa oleifera on albino rats. Internat J of Pharm Tech Res. 2014;6(5), 1441-1449.

17. Feliu J, Ventura J, Segura R, Rodas G, Riera J, Estruch A, Ortís L. Differences between lactate concentration of samples from ear lobe and the finger tip. $J$ of physiol and biochem. 2000;55(4):333-9.

18. Gormley SE, Swain DP, High R,Spina RJ, Dowling EA, Kotipalli US, et al. Effect of intensity of aerobic training on $\mathrm{VO}_{2} \max$. Med and Sci in Sports and Exercise. 2008;40(7),1336-1343.

19. Ghosh AK. Review Article Anaerobic Threshold: Its Concept and Role in. Malay J Med Sci. 2004;11(1), 24-36.

20. Gunawan S, Millah H, Hartadji RH. Hubungan Kadar Haemoglobin Dan Kekuatan Otot Pernapasan Dengan Kapasitas $\mathrm{VO}_{2} \mathrm{Max}$ Pemain Sepak Bola UNSIL UNITED. J Siliwangi. 2017;3(1), 173-178.
22. Pour-abdi K, Shakerian S, Pour-abdi Z, Janbozorgi M. Effects of Short-Term Interval Training Courses on Fitness and Weight Loss of Untrained Girls. Annals of Appl Sport Sci. 2013;1(2), 1-9.

23. Brito VW, Halsberghe M, Schwantes M, Perez S, Baldissera V, Prestes J, et al. Increased lactate threshold after five weeks of treadmill aerobic training in rats. Brazil J of Biol. 2014;74(2),444449.

24. Carte H, Jones AM, Doust J H. Effect of 6 weeks of endurance training on the lactate minimum speed. J of Sports Sci. 1999; 17(12),957-967.

25. Dahl KDA. External Factors and Athletic Performance (Thesis). London : Liberty University; 2013.

26. Chan CB, Ryan DA. Assessing the effects of weather conditions on physical activity participation using objective measures. Internat J of Environment Res and Public Health. 2009;6(10), 26392654. 